$\xi=-1$

\title{
Classification of cargo lifting machines and mechanisms
}

\author{
Vyacheslav V. Sergeev ${ }^{1 *}$, Yuri M. Lyashenko ${ }^{2}$, Kazbek K. Mulukhov ${ }^{3}$, Mikhail V. Gegelashvily \\ ${ }^{1}$ Dr. Tech. Sc. Prof. North Caucasian Institute of Mining and Metallurgy (state technological university) Str. Chkalova, 45-15, Vladi- \\ kavkaz, Russian Federation, 362002 \\ ${ }^{2}$ Dr. Tech. Sc. Prof. Shakhty agency of the Southern-Russian state Polytechnical University, (Novocherkassk Polytechnical Institute \\ ${ }^{3}$ Dr. Tech. Sc. Prof. North Caucasian Institute of Mining and Metallurgy (state technological university) \\ ${ }^{4}$ Dr. Tech. Sc. Prof. North Caucasian Institute of Mining and Metallurgy (state technological university) \\ *Corresponding author E-mail: vv_sergeev_47@mail.ru
}

\begin{abstract}
The studied problem urgency is caused by the fact that now days the cargo-lifting transport machines and mechanisms are considered to be 1 machines group, impeding the study and analysis of the cargo-lifting machines and mechanisms. The article is aimed at the division of the wide class of the lifting-transport machines into 2 classes: cargo-lifting machines and mechanisms and the transport facilities, machines and mechanisms and also the analysis of cargo-lifting machines and mechanisms. The leading approach to this problem study is the collection and generalization of the main information concerning all known constructions of the cargo-lifting machines and mechanisms by classification development of these machines and mechanisms. The cargo-lifting machines and mechanisms, providing the cargo-lifting from one level to another one with the possible shifting in space, restricted by the machine construction were picked out from the transport machines, providing the cargo shifting in the unlimited space one level (horizontal and slightly inclined conveyors, automobile, rail road, sea and river, hydraulic and pneumatic transport ets), resulting in the classification of the cargo lifting machines and mechanisms.
\end{abstract}

Keywords: cargo lifting machines and mechanisms, transport machines, movement in space, restricted with machine construction.

\section{Introduction}

Some authors combine cargo lifting machines and mechanisms together with transport machines into one group but it is more expedient to examine then in separate groups, supposing, that the cargo lifting machines and mechanisms provide cargo lifting from one level to another with a possible shifting in space limited with the machine frame.

\subsection{Methodological Framework}

The transport machines provide cargo displacement in practically unlimited space on one level (horizontal and slightly - inclined conveyors, automobile, rail-way, sea and river, horizontal or slightly-inclined hydraulic and pneumatic transport etc.).

Mankind began to construct machines and mechanisms enhancing a man's muscular and substituting people during the heavy items operation and heavy work fulfillment from the early days. That's why a great variety of classes has been developed, each containing a lot of cargo lifting machines and mechanisms including the simplest levers up to the most complicated robot systems. A lot of these machines and mechanisms can operate autonomously (lifters, capstans, cranes etc.), some of them are built-in the kinematics scheme of more complex machines (hydro lifters, drilling rigs manipulators etc.) and also a great amount of machines with the logical scheme of the mechanized or automated complexes (skip lifters, loaders etc.).

\section{Discussions}

To simplify the study and analysis of all these cargo lifting machines and mechanisms and to develop new effective decisions, a special classification is required. For example, the classification [1] separating cargo lifting machines and mechanisms from the transporting ones determining the machines of the periodic and a periodic operation. The classification [2] divides cargo lifting machines and mechanisms in terms of the construction feature, purpose and character of their work. Then the devoices and some cargo lifting machines and mechanisms such as lifters, winches and cranes are studied more carefully analyzing their positive and negative aspects. There also exists the classification [3] for the complex mechanization devices determining the main and auxiliary appliances.

The main devices of the cargo lifting, loading-discharging and transporting machines are divided into 3 classes: machines of periodic (cyclic) operation, machines of aperiodic (non-stop) operation and the combined equipment. The auxiliary devices are subdivided into gravity-flowing, pocketing devices and the devices for the auxiliary mechanization works without any cargo lifting machines. 


\section{Results}

The presented classification based on the experience of the known classifications, embraces practically all known constructions of the cargo lifting machines and mechanisms and place them into the cells according to the definition given above for all cargo lifting machines and mechanisms ones, when the first group consists of the machines with hand drive, mechanical drive and the hydraulic drive and the second group includes the machines with the mechanical and pneumatic drive.

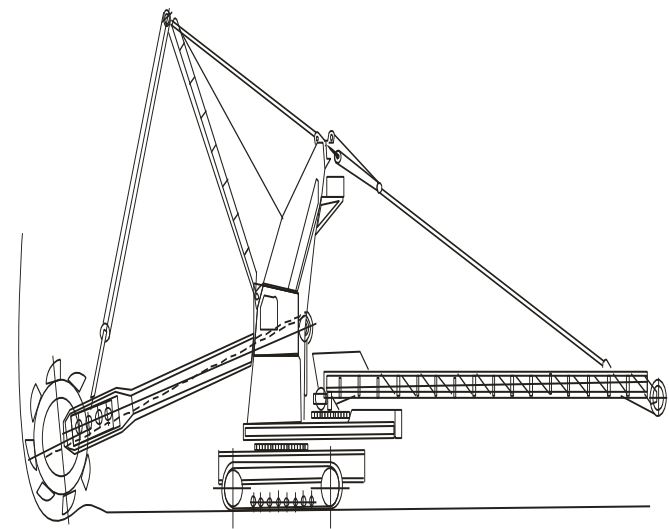

Fig.1. Rotary excavator

The cargo lifting machines and mechanisms of cyclic operation with the hand drive include lever, screw (fig. 2) [1, 2], rack-andpinion (fig. 3) [1, 2], hydraulic jacks (fig. 4) [1, 2] and other jacks. The jacks are mechanisms providing cargo lifting on the small height in the vertical plane without shifting into the horizontal one. Also the levers are included into this group and occupy a special place. A lever developed very early gave birth to the cargo lifting machines and mechanisms construction due to its simplicity, availability and universality and is now often used as a separate device and built-into other mechanisms, for example any wrench, rotating a nut or bolt, the drives, etc.

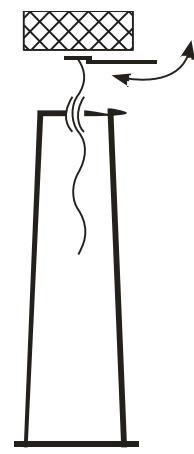

Fig. 2. Screw jack

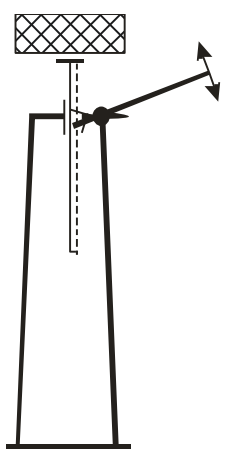

Fig. 3. Rack-andpinion jack

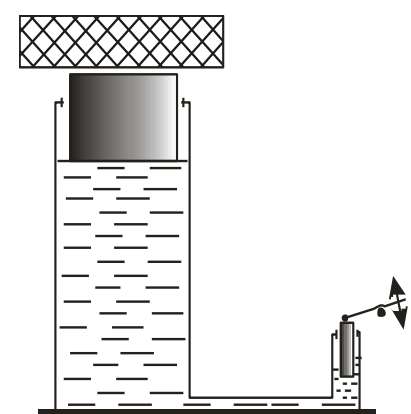

Fig. 4. Hydraulic jack
A lever is the only device in this group which can both lift the cargo and shift it in the horizontal plane. The main feature of the levers and other jacks is the contact point with cargo, support and impact point as for a wrench it's a nut, the support point is the resistance to the nut rotation along the thread.

Among the cargo lifting machines of cyclic operating with a hand drive the following units are known-capstans (fig.5) [1, 2], boat armature hoists, hoist chain (fig. 6) $[1,2]$ and pulley blocks with force enhancement (fig. 7a) [1] and speed enhancement (fig. 7b) [1] and pulleys, placed on one plane (fig. 8a) [1] or on one axis (fig 8b) [1] both single-pass (fig. 7) and multi-pass (fig 8).

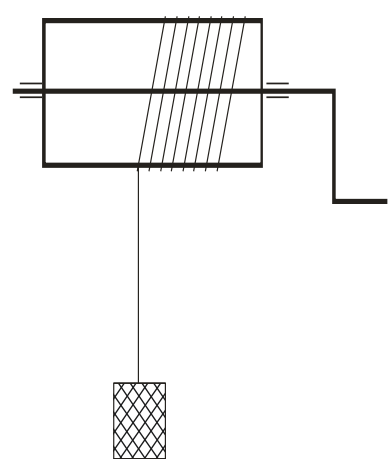

Fig. 5. Capstan

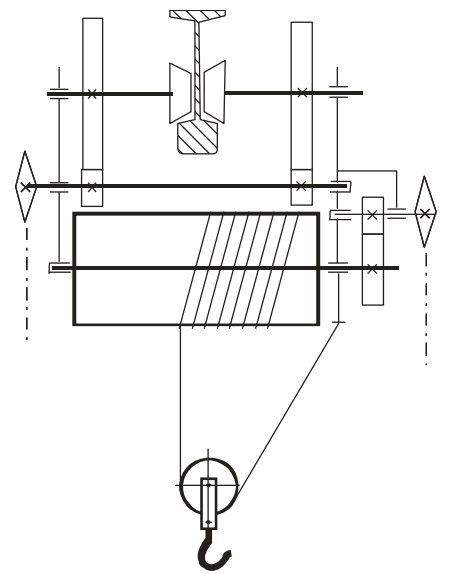

Fig. 6. Hoist chan

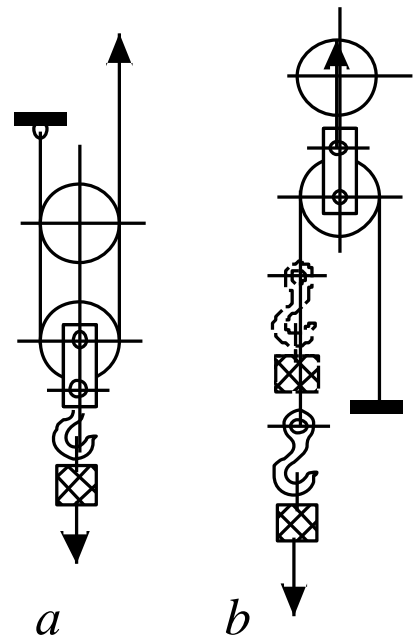

Fig. 7. Both single-pass: a - with forth enhance, $b$ - with speed and distance enhance

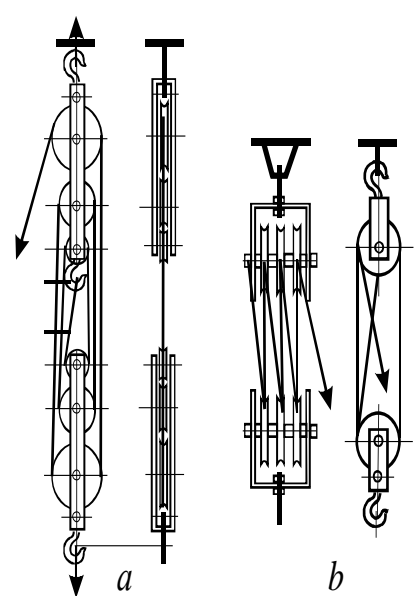

Fig. 8. Multi-pass pulley blocks (6 ручьев): a - pulleys in on plane
Capstan are considered to be the basis of hoists. The main feature of all hoists is the presence of the drum rotation from any drive and the flexible connector (chain, rop etc.) fixed to the cargo with a free end.

Among the cargo lifting machines and mechanisms of cyclic operation with a mechanical drive there exist lifts and lifters: telescopic (fig. 9) [1, 2], pantographic (fig. 10) [1, 2], bucket (fig. 11) $[1,2]$, scip (fig. 12) [1, 2], chain (fig. 13) [3], screw (fig. 14, 15) lifters etc.
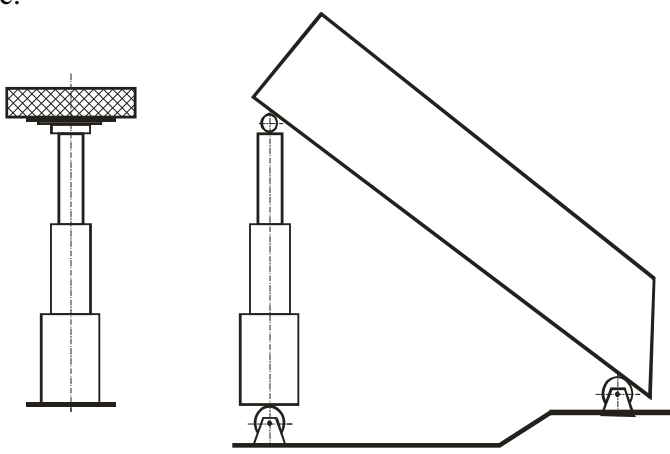

Fig. 9. Telescopic lift versions 


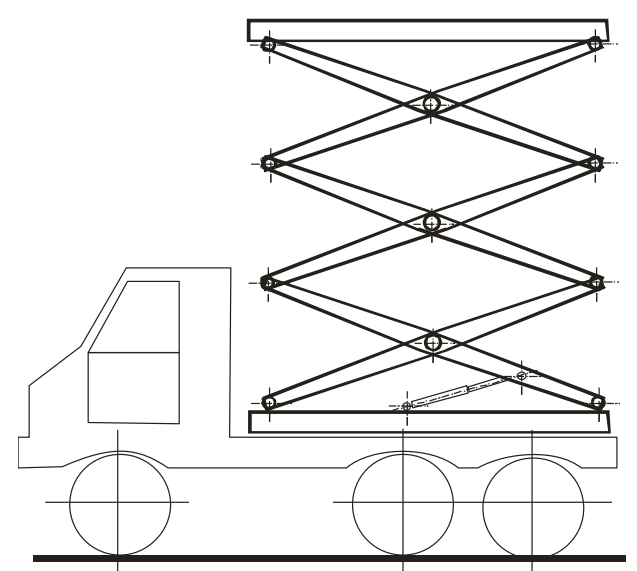

Fig. 10. Pantographic lift
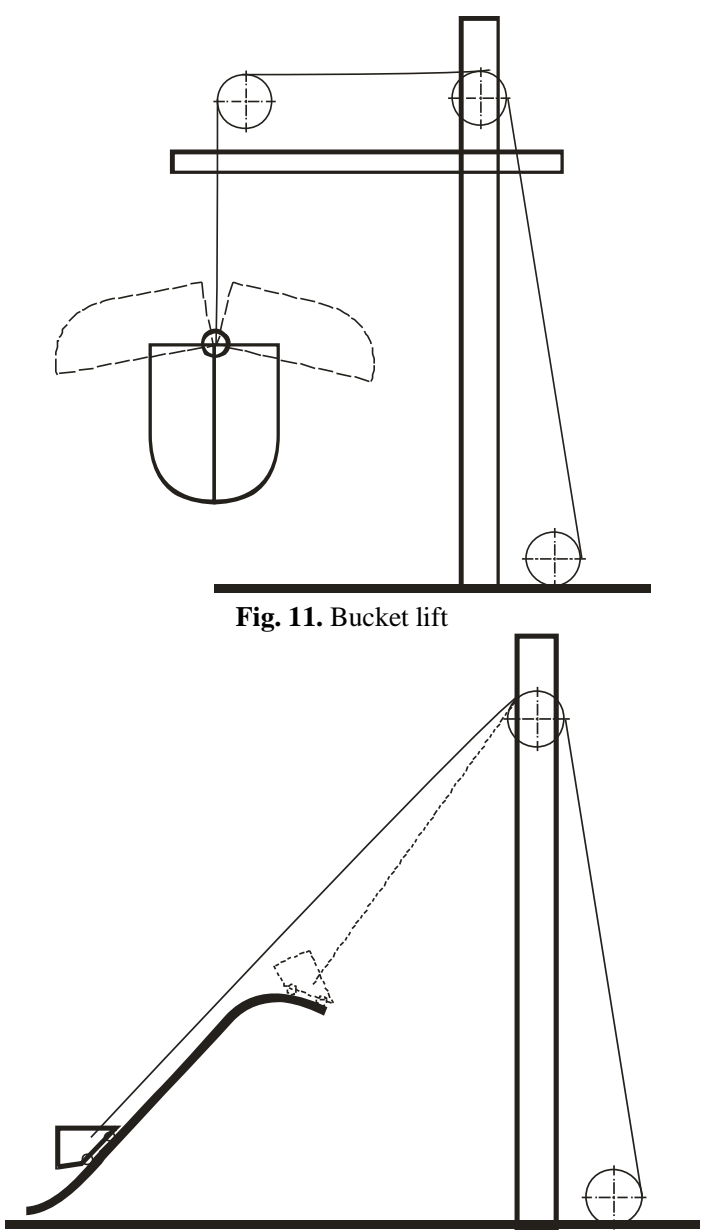

Fig. 12. Skip hoist

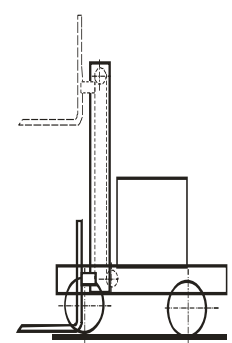

Fig. 13. Chain hoist in the electric stacker

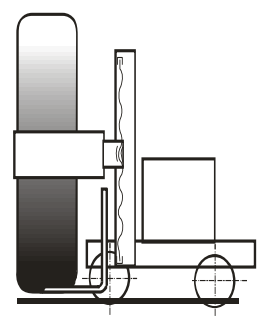

Fig. 14. Screw jack in the wheels lifter

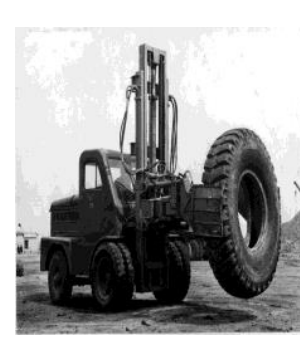

Fig. 15. Wheels lifter (outview)
The main feature of the lift hoist is their independent work without any operator-driver. Cargo lifting is carried out on the fixed level automatically, the necessary level being pointed by the consigner. Other hoists lift and descend cargo on any level (except skip having two levels-loading level and discharging level) under the operator's control.

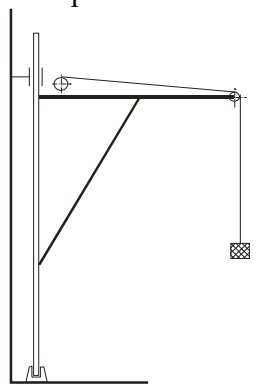

Fig. 16. Bracket crane with a constant

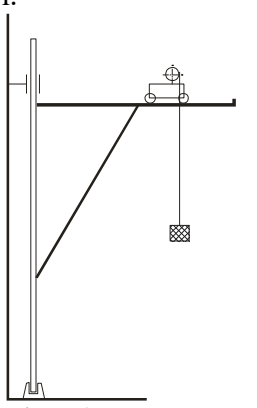

Fig. 17. Bracket crane with variable boom

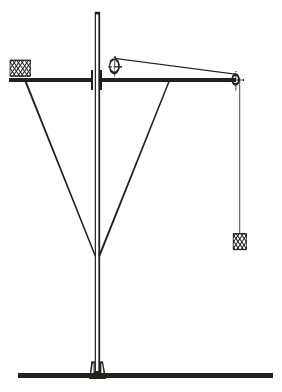

Fig. 18. Bracket crane holoturn

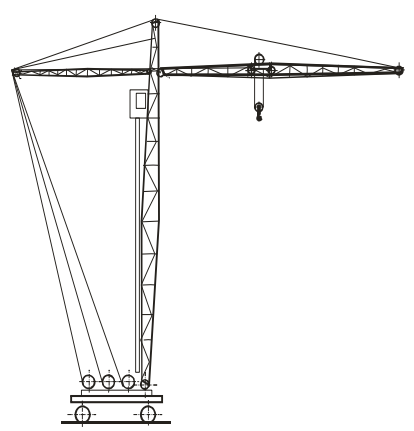

Fig. 19. Tower crane

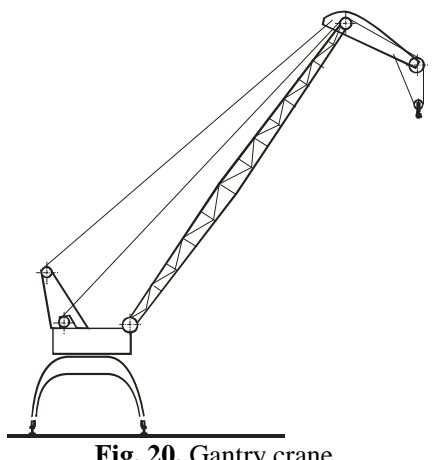

Fig. 20. Gantry crane
By design the lift themselves provide lifting (descending) of cargo without shifting in the horizontal plane, that's why a mobile base for the their sanctions increase is mounted under them. The pantographic lift is mounted on the automobile base (fig. 10), chain hoist is used in the electric stacker (fig. 13), the screw lift is mounted on the wheels lifter (fig. 14, 15) also there is one more group of the cargo lifting machines and mechanisms of cyclic operating with the mechanical drive - cranes. As for the cranes they not only lift (descend) cargo, but shifting in the horizontal level.

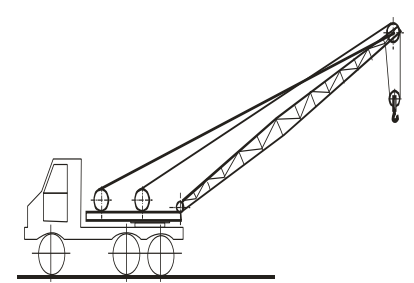

Fig. 21. Truck hoist

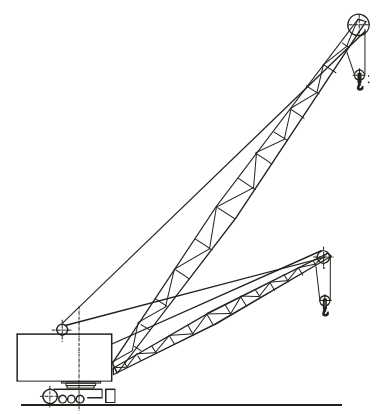

Fig. 22. Crawler crane
There are principle constructive schemes of cranes which may be of jib, flying or bridge type. The jib cranes are divided into cantilever, tower, gantry and with the constant boom (fig. 16) [1, 2], with the variable boom (fig. 17) [1, 2] and holoturn cranes (fig. 18) $[1,2]$.

Also there are tower (fig. 19) [1, 2, 3, 4] and gantry cranes (fig. 20) $[1,2,3,4]$. There are also mobile cranes: automobile (fig. 21) [1, 2, 3, 4], crawler cranes (fig. 22) [1, 2, 3, 4], floating cranes (fig. 23) $[1,2,3,4]$ and railroad cranes (fig. 24) $[1,2,3,4]$. The mobile cranes differ only in the design of the self-propelled base and jib. 


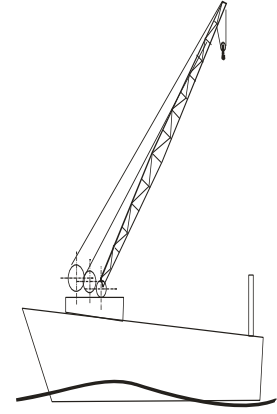

Fig. 23. Floating crane

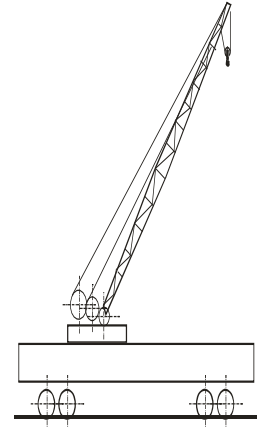

Fig. 24. Rail-road crane

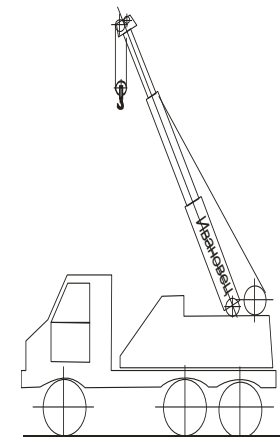

Fig. 25. Mobile telescopic crane
Now days the truss jibs are substituted, by the telescopic jibs (fig. 25). This is due to the small dimensions in the transportation position which gives possibility to work with halffull sliding jib and position the cargo turning (descending) or sliding the jib.

Studying the jib cranes it is obvious that they are equipped with one-support jib and they operate on the round territory with the center coinciding with the crane base rotary axis. To expand the service area the tower or port cranes are used moving along the oval area on the rails.

The cranes with the mechanical drive include bridge, telpher cranes (fig. 26) [1, 2, 3, 4], bridge cranes (fig. 27) [1, 2, 3, 4, 5], gantry cranes (fig. 28) [1, 2, 3, 4, 5], cable cranes (fig. 29) [1, 2, 3, 4], etc. These cargo lifting mechanisms shift along the beam with two supports, then move perpendicularly (except the cable crane) resulting in the rectangular service area without dead spots, as for the flying cranes $[1,2,3,4,5]$, they cover free and unlimited area and their cargo lifting mechanism is mounted on the helicopters or airships.

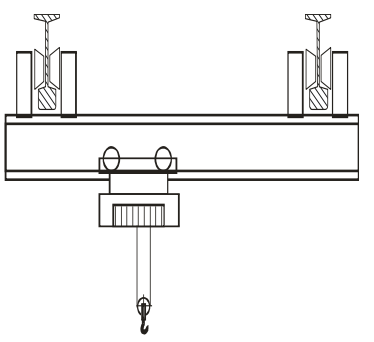

Fig. 26. Suspended vib

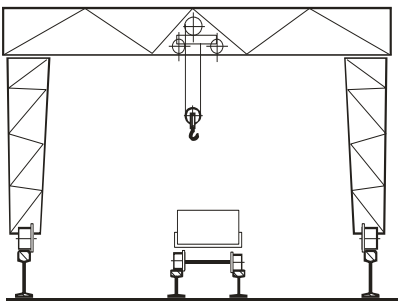

Fig. 28. Gantry crane

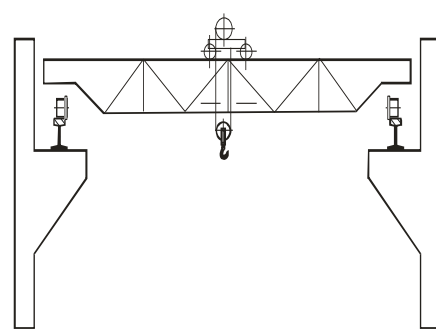

Fig. 27. Bridge crane

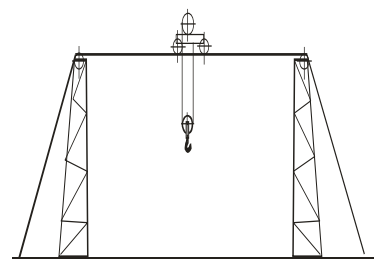

Fig. 29. Cable crane
The main element of all cranes with the cargo contact is a hook. The adaptation to various cargoes is made using the auxiliary devices. Sometimes The cranes are specified for a certain cargo type and they become special then, for example in case the crane is equipped with forks as a forklift to work with the pallets, so it becomes a stabler [5], if the crane transfers a mould for the hot metal it becomes a metallurgical one [5], if greifer is used, the crane becomes a greifer one [5] etc. The crane construction isn't changed in all these cases.
The most common use belongs to the hoists being the machines or the cyclic operation with a mechanical drive. They are widely used both as the autonomous mechanisms and the built-in one (lifters, cranes etc.). There is no principal difference in the hoists construction. They all consist of a drive, reductor, drum (drums) and brake. The main difference is in the braking pads drive. There are one-drum hoists (fig. 30) ding used both autonomously and in other mechanisms compositing.

The built-in hoists have an electric brake drive [1, 2, 3, 4, 5]. Scraper hoists with two and three drums with the co-axial and parallel drive position (fig. 31 and 32) [1, 2, 3, 4, 5] and electric capstan winch with horizontal and vertical drum position (fig. 33) $[2,5]$ are widely used as the autonomous mechanisms. All scraper hoists have a hand drive of the brakes under the scraper-operator control. The stronger the brake drum claps, the more draught effort makes a hoist. This is due to the planetary reductor use which has a freely rotating brake drum.

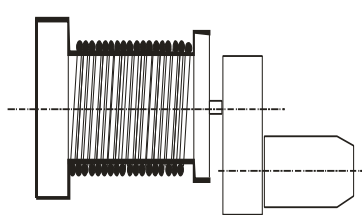

Fig. 30. Single-drum hoist
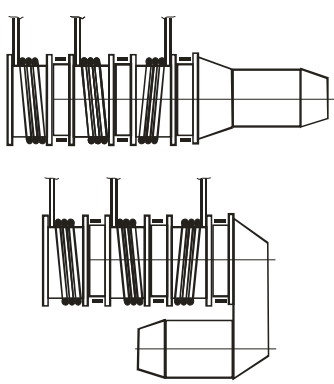

Fig. 32. Scraper three-drum hois with co-axis and parallel engine position
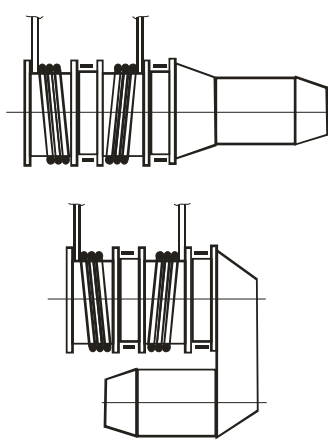

Fig. 31. Double-drum hoist with co axis and parallel engine position
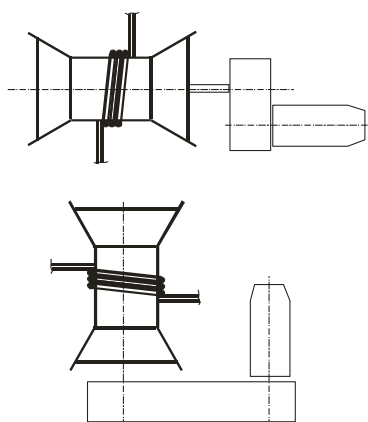

Fig. 33. Electric capstan winch with horizontal and vertical drum position
The distinctive feature of the capstan winch is the fact that the rope end isn't fixed on the drum. The effort transfer from the rotary drum to the rope is done due to the friction loops. This allows using the rope of the "endless" length. The draught effort is regulated with the force applied to the dead run of the rope.

A special group of the cargo lifting machines and mechanisms consists of the loaders. They have a scooping device instead of the hook and are considered special cargo lifting machines which not only lift and shift the cargo but also scoop this cargo without any additional devices. There are loaders of cyclic operation with a bucked with the back discharging into the trucks (PPN-1...PPN-3) or on the built-in conveyor (fig. 34) [6] and the front discharging PD-2 (fig. 35) [6] and many other loading-delivery machines (Tamrock, Atlas Copko etc.).

Also a special group of the loaders with the cyclic operation consists of excavators. There are straight scoop excavators (fig. 
36) [7], pull scoop excavators (fig. 37) [7], dragline excavators (fig. 38) [7] and scrapers (fig. 39) [7].

Among the cargo lifting machines of the cyclic operation with the mechanical drive there exist hoisting engines without practical distinction from the hoists. They differ only in the big sizes and the drum configuration.
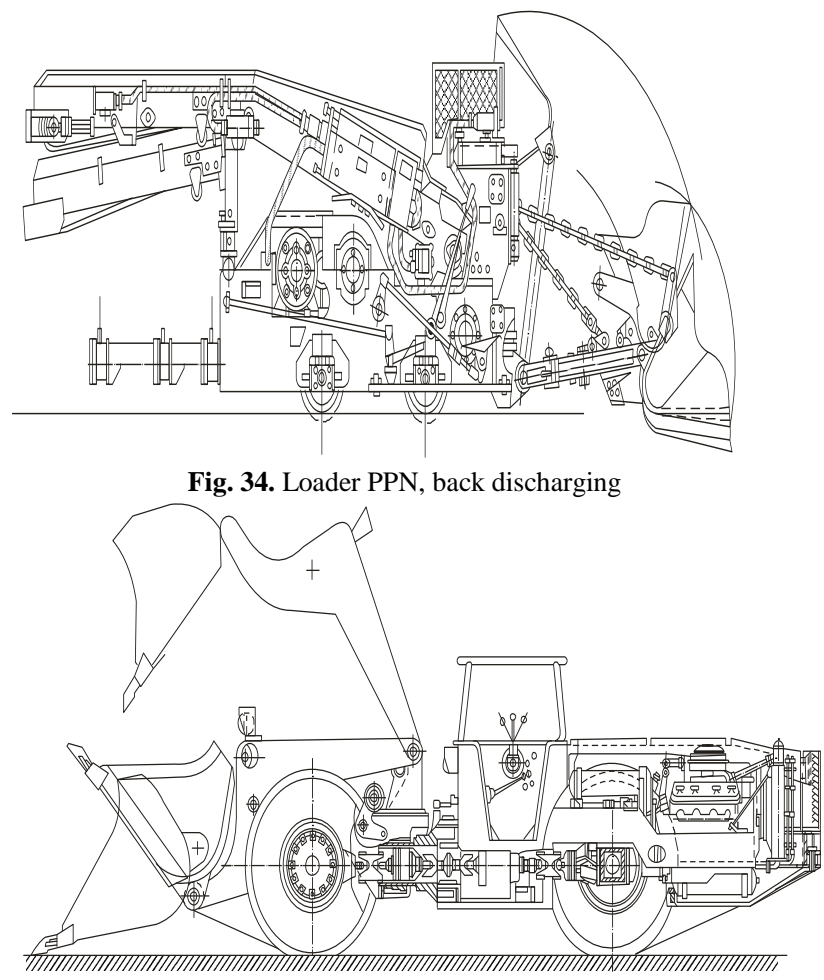

Fig. 35. Loader DK-2, front discharging

The lifters can be one-drum, two-drum and one-cut drum ones. The drums, as a rule, are cylindrical but also may be bycylindrical. The lifting rope is inserted into the drum with one end while the second end is linked with the lifting vessel.

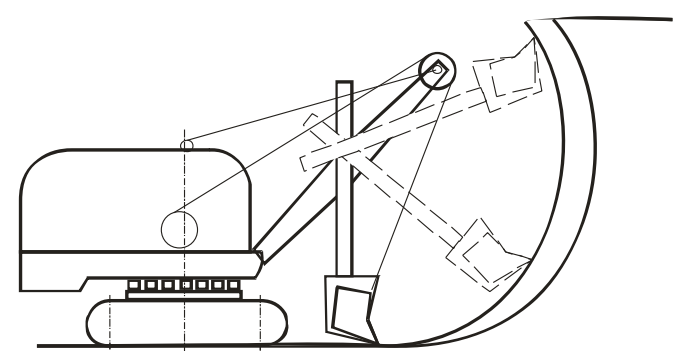

Fig. 36. Straight scoop excavator

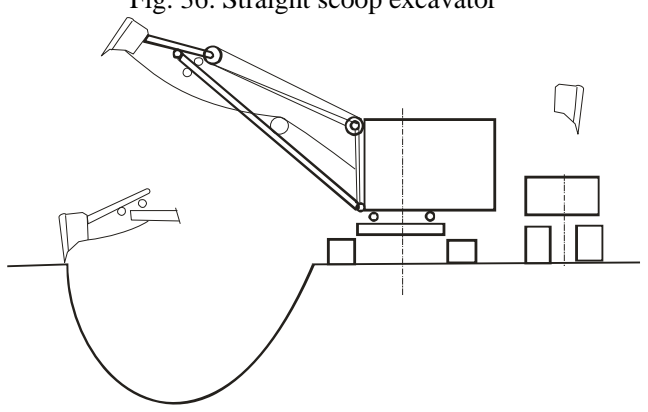

Fig. 37. Pull scoop excavator

There also exist the lifting machines with the friction pulley, across which one, two or four lifting ropes called multiropes are overthrown. The hoist engines serve for the cage lifting, sceep lifting and bucket lifting.

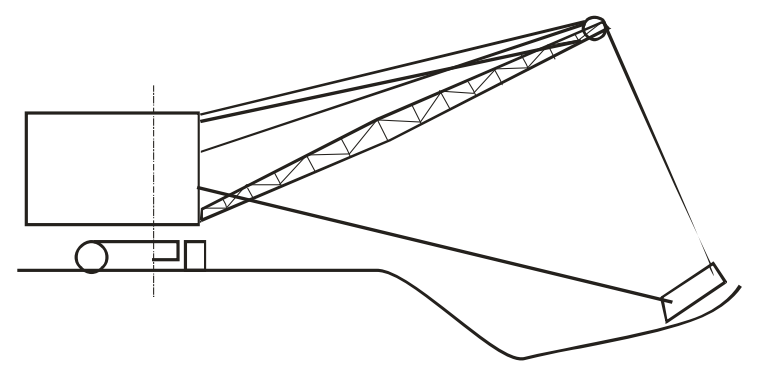

Fig. 38. Dragline excavator

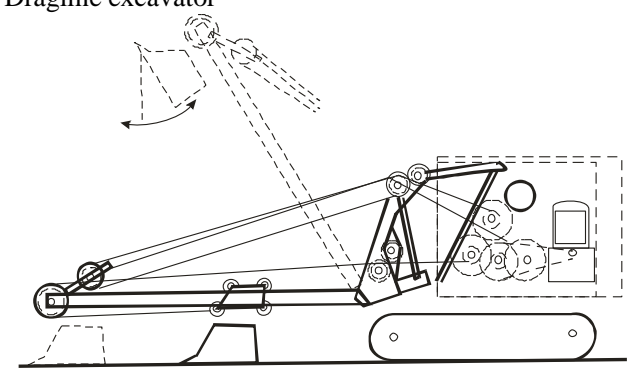

Fig. 39. Scraper

The cage and bucked lifting is universal, while the sceep one is specialized. A small group of the cargo lifting machines and mechanisms of the cyclic operation constitute the cargo lifting machines and mechanisms with the hydraulic (pneumatic) drive, such as jacks: outriggers (fig. 40), pneumatic cushions (fig. 41). The jacks-outriggers are constructed

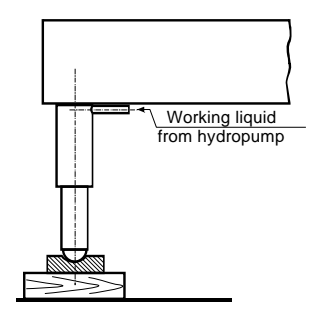

Fig. 40. Outrigger

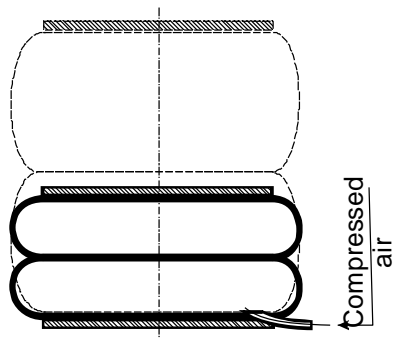

Fig. 41. Pneumatic cushion
Hydro elevators (fig. 42) [6] and air lifts are included into the group of the cargo lifting machines and mechanism of the continuous operation. The hydro monitor washout (fig. 43), rotary water lifter (fig. 44), loaders of hydro transport and pneumo transport [9] fall into that group.

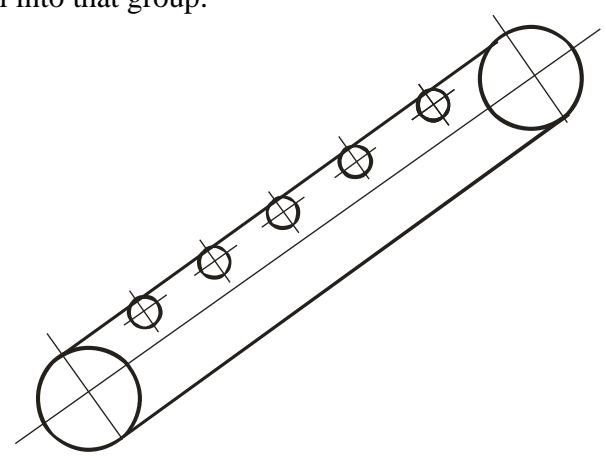

Fig. 42. Steep-inclined band conveyor 


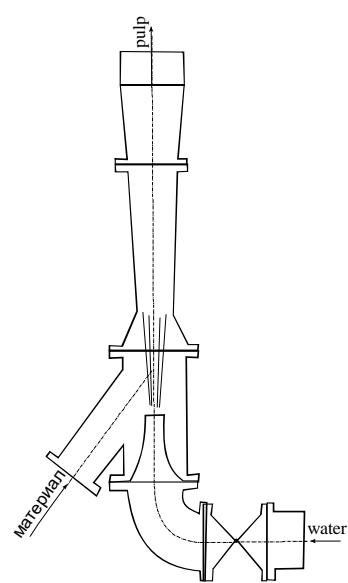

Fig. 43. Hydro elevator

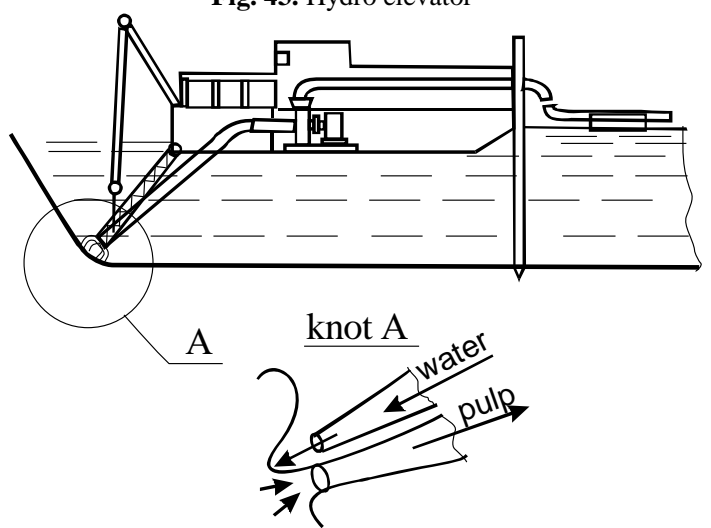

Fig. 44. Bucket dredger with hydrowashout

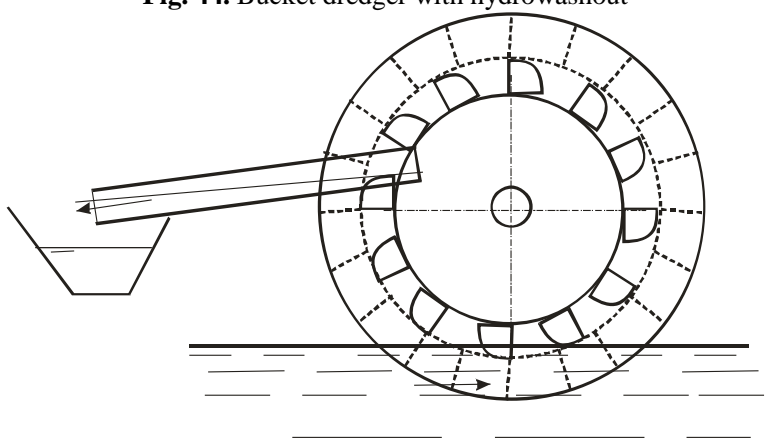

Fig. 45. Rotary water lifter

\section{Conclusion}

The definition of the cargo-lifting machines and mechanisms was specified. Lt allowed to determine more specific class of the cargo-lifting machines and mechanisms, providing the possibility of more detailed study and system analysis of all known constructions of such machines classifying them into subclasses and groups. The proposed classification is useful to the service engineers of hoisting machines and mechanisms and it is necessary for scientists, designers and designers, who study, study and develop new promising models of load-lifting machines and mechanisms.

\section{References}

[1] Dodonov B.P., Lifanov V.A. Gruzopodyomnye i transportnye ustroistva. M. Mashinostroenie., 1990. - $248 \mathrm{~s}$.

[2] Alexandrov M.P. Podyomno- transportnye mashiny. M. Vysh. Shk., 1985. $520 \mathrm{~s}$

[3] Starovoitov V.K. Tyagolye raboty - mashinam. Leningrad, 1975. - $126 \mathrm{~s}$

[4] Abramovich I.I. et al. Gruzopodyomnye krany promyshlennykh predpriyatiy: Spravochnik. M.: Mashinostroenie., 1989. - 360 s.
[5] Petukhov P.Z., Ksyunin G.P., Serlin L.G. Spetsialnye krany. M. Mashinostroenie., 1985. - $248 \mathrm{~s}$.

[6] Kantovich L.I., Merzlyakov V.G. Gornye mashiny i oborudovanie dlya podzemnykh gornykh rabot. M.: Izd-vo MGGU, 2013. -408 s.

[7] Mashiny i oborudovanie dlya shakht i rudnikov: Spravochnik / S.Kh. Klorikyan, V.V. Starichnev, A.G. Laptev et al. M.: MGGU, 2002. $-471 \mathrm{~s}$.

[8] Kartavyi N.G. Statsionarnye mashiny. M.: Nedra, 1981. - 327 s.

[9] Sergeev V.V. Klassifikatsiya konstruktsiy zaryadchikov, primenyaemykh na proizvodstve. Byul. "Tsvetnaya Metallurgia", 1979,24, str. 15

[10] Sergeev V.V. Klassifikatsiya gruzopodyomnyh mashin i mehanizmov. Chast I. Gornye oborudovanie i elektromehanika, 2016, № 2, str. 40-44

[11] Sergeev V.V. Klassifikatsiya gruzopodyomnyh mashin i mehanizmov. Chast II. Gornye oborudovanie i elektromehanika, 2016, № 3, str. 20-26

[12] Sergeev V.V. Klassifikatsiya gornyh mashin i oborudovaniya na osnove ponyatino-soderjatelnogo podhoda sistemnogo analiza. Vladikavkaz: izdatelstvo OOO NPKP "MAVR", 2016. - 96 s.

[13] Galkin V.I., Sheshko E.E. Transportnye mashiny. M.: MGGU, 2010. $-588 \mathrm{~s}$.

[14] Kantovich L.I., Hazanovich G.Sh., Volkov V.V., Voronova E.Yu., Otrokov A.V., Chernyh V.G. Mashiny i oborudovanie dlya gorno-stroitelnyh rabot. M.: MGGU, 2011. - $445 \mathrm{~s}$.

[15] Transport na gornyh predpriyatiyah. Pod obsh. redaktsiey Kuznetsova B.A. / Kuznetsov B.A., Rengevich A.A., Shorin V/G. dr. M.: Nedra, 1976. -552 s.

[16] Muluhov K.K. Transportnye mashiny na gornyh predpriyatiyah USA. M.: Nedra, 1981. - $190 \mathrm{~s}$

[17] Grishko A.P. Statsionarnye mashiny. Tom 1. Rudnichnye podeymnye ustanovki. M.: MGGU, 2008. - 477 s.

[18] Grishko A.P. Statsionarnye mashiny. Tom 2. Rudnichnye vodootlivnye, ventilyatornye i pneumaticheskie ustanovki. M.: MGGU, 2007. - $586 \mathrm{~s}$.

[19] Podyomno- transportnye mashiny. http://www.twirpx.com/ /files/machinery/ntm/

[20] Podyomno- transportnye mashiny. http://www.knigka.info/2010/03/31/podemno-transportnyemashiny.html

[21] Podyomno- transportnye mashiny. Александров М. П. Izdatelstvo«Vysshaya shkola», 1985 http://www.booksgid.com/technology/19937-.html

[22] 22. Shestopalov K.K. Podyomno- transportnye stroitelnye i dorojnye mashiny i oborudovanie. https://dwg.ru/dnl/3560

[23] Vorobiev Yu.V.Podyomno- transportnye mashiny. Издательство: Тамб. гос. техн. ун-та, 2001. https://eknigi.org/tehnika/143353-podemno-transportnyemashiny.html

[24] Podyomno- transportnye mashiny. http://translate.academic.ru/ /ПОДЬЕМНО-ТРАНСПОРТНЫЕ\%20МАШИНЫ/ru/en

[25] A. Vaiynson. Podyomno- transportnye mashiny stroitelnoiy promyshlenosti. Atlas konstruktsiiy. 2009. 